\title{
REVISION OF NEOALSOMITRA (CUCURBITACEAE)
}

\author{
W.J.J.O. DE WILDE \& B.E.E. DUYFJES \\ Nationaal Herbarium Nederland, Universiteit Leiden branch, \\ P.O. Box 9514, 2300 RA Leiden, The Netherlands; e-mail: dewilde@nhn.leidenuniv.nl
}

\section{SUMMARY}

Neoalsomitra contains 11 species, one of which, $N$. clavigera, is widespread, covering the whole range of the genus from NE India and S China into Australia and the Pacific. The genus is heterogeneous in having species with free stamens and species with the filaments connate; however, this cannot be used for subdivision. Neoalsomitra hederifolia and N. schefferiana are podagric succulents, i.e. with thickened stem-bases. Neoalsomitra pilosa W.J. de Wilde \& Duyfjes (New Guinea) is newly described; new combinations are N. hederifolia (Decne.) W.J. de Wilde \& Duyfjes and N. schefferiana subsp. podagrica (Steenis) W.J. de Wilde \& Duyfjes.

Key words: Cucurbitaceae, Neoalsomitra, SE Asia.

\section{INTRODUCTION}

After its segregation from Alsomitra (Hutchinson, 1942) the SE Asian genus Neoalsomitra (subfam. Zanonioideae, subtribe Zanoniinae) has remained very heterogeneous; it contains annual as well as long-lived perennial species.

The definition and distinction of genera within Cucurbitaceae is not particularly problematic, but has led to a comparatively large proportion of monotypic genera. A criterion of good standing is whether the filaments are free or united into a column. However, in Neoalsomitra, a genus with 11 species, about half of the species have the filaments partially or completely fused in contrast to species with free stamens. Rather than splitting up the genus again, we prefer to maintain its present circumscription and accept this variable character state as a peculiarity of Neoalsomitra (though a similar variation is sporadically known in other genera, e.g. in Coccinia of subfam. Cucurbitoideae). This means that within subfamily Zanonioideae male flowering specimens of those species of Neoalsomitra in which the stamens are fused can no longer be keyed out in a simple way from Gynostemma (a genus with fused stamens, but different in many respects).

The Australian N. capricornica forms with N. pilosa and N. schultzei (New Guinea) the most aberrant group of species, tempting its splitting off into a separate genus, when compared for instance with $N$. clavigera. The latter also occurs in Australia and New Guinea and is readily distinct by its stout, perennial habit, and compound leaves. The characters uniting the former 3 species are: 1) more tiny, annual growth habit; 2) leaves simple, entire or coarsely dentate, or palmately lobed or palmatisect; 3 ) flowers monoecious, with the solitary fruit (female flower) borne on the otherwise male-flowered panicle; 4) perianth of male flowers at anthesis rather bowl-shaped, not flattish-rotate; 
5) filaments united into a column; 6) capsules thin-textured, small. However, most of these characters appear not to be unique when compared to the characters of the other species of Neoalsomitra: an annual growth habit is found in N.plena (Thailand); simple, entire or lobed leaves are shared with $N$. simplex and N. plena (both Thailand); a bowl-shaped perianth at anthesis is shared with $N$. simplex and $N$. hederifolia (Lesser Sunda Islands); filaments wholly or largely united into a column are also found in $N$. angustipetala (Thailand), N. hederifolia and N. schefferiana (E Malesia); small, thintextured capsules are shared with $N$. plena and N. schefferiana. Only the monoecism and the solitary female flowers seem to hold as separating characters. Although sex expression surely is a distinctive quality in genus delimitation, monoecious species are found for instance among the species of the mainly dioecious Trichosanthes.

We have refrained from subdividing the genus, also because the winged seeds in all eleven species of Neoalsomitra are remarkably uniform (Fig. 1).

\section{NEOALSOMITRA}

Neoalsomitra Hutch. (1942) 97. - Lectotype: Neoalsomitra sarcophylla (Wall.) Hutch.

Alsomitra M. Roem. (1846) 117, p.p. (non Zanonia sect. Alsomitra Blume); Hook.f. (1867) 840; Cogn. (1881) 928; (1916) 11.

Climbers, annual or perennial, with or without tuberous rootstock. Leaves simple or compound, subcircular in outline, lateral leaflets sometimes smaller and unequal sided, margin mostly entire. Tendrils 2-branched at apex. Flowers dioecious or monoecious, small, pale creamy yellowish or greenish. Inflorescences lateral (and terminal), in male mostly many-flowered, paniculate with ultimate branches fine, raceme-like, pedicels persistent; in female paniculate or raceme-like, fewer-flowered. Male flowers: rotate or broadly bowl-shaped; receptacle flat or shallow; disc absent or in N. schultzei inconspicuous; sepals 5 , free; petals 5 , imbricate in bud, very short-connate at base; stamens 5 , inserted centrally, \pm out-curved, filaments free or partially or wholly fused, anthers small, 1-thecous, extrorse, often with a minute dark dot adaxially. Female flowers: ovary cylindrical-clavate, imperfectly 3-locular, ovules $5(-10)$ per placenta, pendulous, styles 3 , short, stigma deeply lunate; staminodes present only in N.plena. Fruits medium-sized cylindrical-clavate capsules, apex truncate, 3-valvate, perianthscar 0.5-2(-2.5) mm from orifice. Seeds alternate in each row (wings imbricate), flat, faces (finely) tubercled or smooth, margin narrow or broad, double (not or hardly so in $N$. balansae, $N$. sarcophylla), subentire or finely or coarsely dentate, with apically an \pm oblique membranous translucent wing.

A genus of 11 species, distributed from NE India and S China to Australia and into the Pacific, 1 species, $N$. clavigera, covering the whole area of the genus.

\section{KEY TO THE SPECIES}

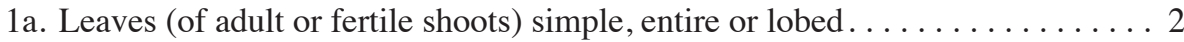

b. Leaves (of adult or fertile shoots) compound . . . . . . . . . . . . . . 7

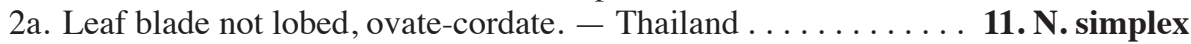

b. Leaf blade \pm 5 -angular, or shallowly to deeply (palmately) lobed, ovate or subcir-

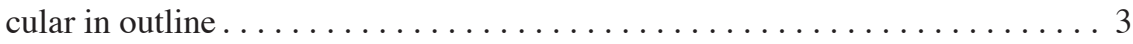


3a. Dioecious; plant not tuberous. Petals \pm elliptic-oblong, long-acute. Filaments

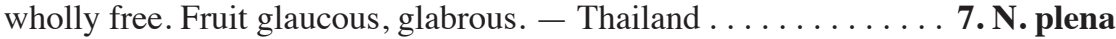

b. Monoecious or dioecious; plant tuberous (always?). Petals (ob)ovate, \pm obtuse, mucronate or not. Filaments partly or wholly united. Fruit green, glabrous or hairy.

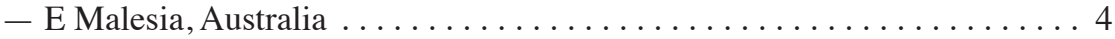

4a. Dioecious(?). Plant tuberous. Inflorescences (infructescences) twice branched. Petals adaxially papillose. Filaments largely or completely fused. Fruit glabrous.

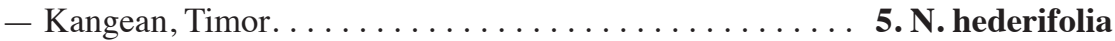

b. Monoecious. Plant not tuberous(?). Inflorescences not or once-branched. Petals adaxially not papillose. Filaments connate in the lower half. Fruit glabrous or

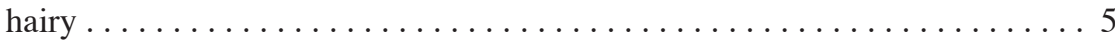

5a. Plant, including fruit, densely soft-hairy, drying (dark) brown. - E Papua New Guinea ...................... pilosa

b. Plant subglabrous or sparsely hairy, drying green. Fruit glabrous or sparsely

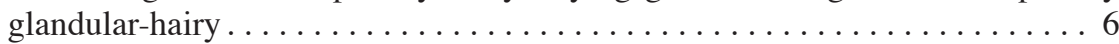

6a. Fruit glabrous. [Fruit (female flower) solitary on the node or in otherwise male panicle.] - Papua New Guinea...................10. N. schultzei

b. Fruit sparsely hispid-glandular hairy. [Fruit (female flower) borne on otherwise male panicle (always?).] — NE Queensland . . . . . . . 3. N. capricornica

7a. Leaves 3-foliolate, petiole less than $0.5 \mathrm{~cm}$ long; leaflets carnose, wrinkled on drying, apex usually obtuse. Fruit 3-4 cm long. Seeds shortly 2-horned. - SE Continental Asia, E Malesia. . . . . . . . . . . . . . 8. N. sarcophylla

b. Leaves 3- or 5-foliolate, petiole $0.5-3(-5) \mathrm{cm}$ long; leaflets membranous (slightly carnose in N. balansae), not wrinkled on drying, apex (obtuse or) acute. Fruit 2-8 $\mathrm{cm}$ long. Seeds entire, or horned, or star-shaped by coarsely 5-7 (double) dentate

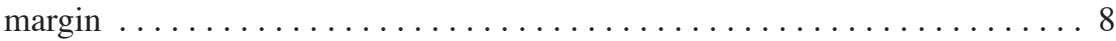

8a. Apex of leaflets obtuse or acute. Stamens wholly united into a column. Male petals narrow, linear, resembling and about as long as sepals. [Fruit $4-6 \mathrm{~cm}$ long. Seed margin sub-entire.] - Thailand ............. 1. N. angustipetala

b. Apex of leaflets acute. Stamens free or partly united. Male petals wider, ovate to (narrowly) elliptic, much longer than sepals . . . . . . . . . . . . 9

9a. Small climber to $5 \mathrm{~m}$ long, not tuberous. Male panicles narrow; perianth c. $8 \mathrm{~mm}$ diameter. [Fruit c. $2.5 \mathrm{~cm}$ long, glaucous.] — Thailand . . . . . . 7. N. plena

b. Robust climber, $5 \mathrm{~m}$ long or more, tuberous or not. Male panicles broad or narrow;

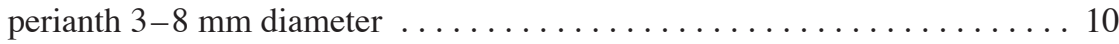

10a. Filaments partly united. Fruit c. $2 \mathrm{~cm}$ long. Stem towards base thorny. - East Malesia .......................... 9. N. schefferiana

b. Filaments free. Fruit 4-8 cm long. Stem not thorny. - SE Asia, Malesia, Australia, Pacific............................... 11

11a. Leaves 3-foliolate, petiole rather short, $0.5-1 \mathrm{~cm}$ long; leaflets slightly carnose, without glands. Fruit 5-6 cm long, narrowed at base. Seeds longly 2-horned.

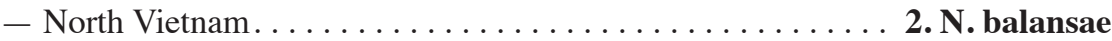

b. Leaves 3-5-foliolate, petiole comparatively longer, $0.5-3(-5) \mathrm{cm}$ long; leaflets not carnose, often with glands on margin at base of lateral leaflets. Fruit $4-8 \mathrm{~cm}$ long, base narrow or broad. Seeds coarsely 5-7-toothed, star-shaped - SE Continental Asia including S China through East Malesia to Australia and the Pacific 

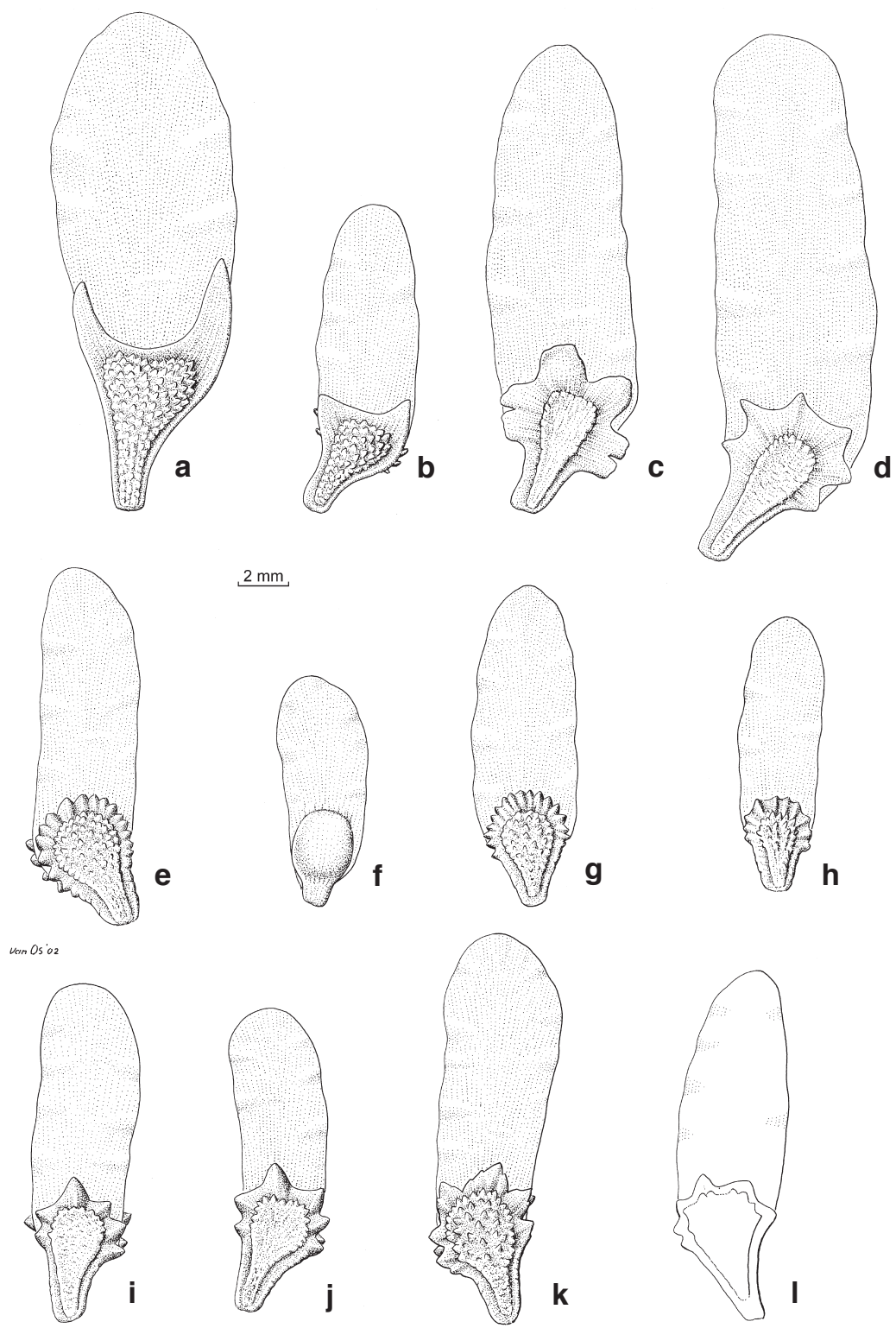

Fig. 1. Seeds of Neoalsomitra. a. N. balansae (Gagnep.) Hutch.; b. N. sarcophylla (Wall.) Hutch.; c. N. clavigera (Wall.) Hutch.; d. N. simplex (Craib) Hutch.; e. N. angustipetala (Craib.) Hutch.; f. N. plena (Craib) Hutch.; g. N. schefferiana (Cogn.) Hutch. subsp. schefferiana; h. N. schefferiana (Cogn.) Hutch. subsp. podagrica (Steenis) W.J. de Wilde \& Duyfjes; i. N. hederifolia (Decne.) W.J. de Wilde \& Duyfjes; j. N. pilosa W.J. de Wilde \& Duyfjes; k. N. schultzei (Cogn.) Hutch.; 1. N. capricornica (F. Muell.) Hutch. (a: Balansa 4022, Vietnam; b: Maxwell 00-163, Thailand; c: Chuang 3172, Taiwan; d: Maxwell 89-80, Thailand; e: Pooma et al. 3037, Thailand; f: Pooma et al. 2102, Thailand; g: Teijsmann 11854, Celebes; h: Pleyte s.n., Bogor, garden number XVIII-A-45a, orig. Timor; i: Anonymous, barcode P218587, Timor; j: Carr 12477, Papua New Guinea; k: Brass 8149, Papua New Guinea; 1: adapted from Fig. 36H in Telford, 1982). 
1. Neoalsomitra angustipetala (Craib) Hutch. - Fig. 1e, 2

Neoalsomitra angustipetala (Craib) Hutch. (1942) 99. - Gynostemma angustipetala Craib (1913) 69. - Alsomitra angustipetala (Craib) Craib (1931) 767. - Type: Kerr 1332 (lecto K, here chosen), N Thailand (Doi Sootep).

Perennial climber, 2-4 m tall, with tuberous root (Fig. 2a), puberulous, stem glabrescent; dioecious. Leaves (3-)5-foliolate (see notes), membranous or thinly chartaceous, 4-10 cm diam., glands absent; petiole 1-2.5 cm long; leaflets all separately stalked, petiolules to $1 \mathrm{~cm}$ long, elliptic or oblong(-oblanceolate), $2-10$ by $2-2.5 \mathrm{~cm}$, base \pm attenuate, apex (sub)acute or obtuse, sometimes \pm retuse, 1-2 mm mucronate, lateral veins 3-5 per side, the lower strongest, veins densely short pubescent. Male inflorescences paniculate, $5-15$ by $3-10 \mathrm{~cm}$, rachis and branches puberulous; bracts linear, $2-3$ mm long. Male flowers: 1(-3) per bract, pedicel 3-6 mm long, bud ovoid; perianth rotate, $6-8 \mathrm{~mm}$ diam., receptacle flat, c. $1 \mathrm{~mm}$ diam., sepals and petals very similar, $10(-14)$ in number, whole flower sparsely glandular hairy. Sepals lanceolate-linear, c. $3 \mathrm{~mm}$ long, acute. Petals 3-4 by $0.4-0.7 \mathrm{~mm}$. Filaments connate into c. $0.5 \mathrm{~mm}$ long column (occasionally one stamen free); anthers ( 3 or) 5 , less than $0.5 \mathrm{~mm}$ long, free or rarely two connate. Female inflorescences raceme-like, to $5 \mathrm{~cm}$ long. Female flowers ovary conical, 4-6 $\mathrm{mm}$ long, subglabrous, styles less than $0.5 \mathrm{~mm}$ long, stigma lobulate, perianth \pm as in male. Capsule solitary or up to 10 per infructescence; capsule 4-6.5 cm long, base short or long attenuate, apex truncate, $1-1.5 \mathrm{~cm}$ wide, glabrous; fruiting pedicel 4-10 mm long. Seeds many, obpyriform, 6-7.5 by 4-6 mm, margin narrow, finely tuberculate, faces finely tuberculate, wing $8-13$ by $4-7 \mathrm{~mm}$.

Distribution - Endemic to Thailand.

Habitat \& Ecology - In mixed (deciduous, dry) dipterocarp and bamboo forest, also on limestone; altitude 100-400 m.

Notes -1 . The completely united stamens in this species are reminiscent of the genus Gynostemma.

2. The first leaves of shoots of the sprouting tuber are simple and slightly fleshy in the fresh state. Leaves in adult plants are normally 5 -foliolate, but 3-foliolate in association with inflorescences.

\section{Neoalsomitra balansae (Gagnep.) Hutch. - Fig. 1a}

Neoalsomitra balansae (Gagnep.) Hutch. (1942) 101. - Alsomitra balansae Gagnep. (1918) 371; (1921) 1090, f. 127, 2-3. - Type: Balansa 4022 (lecto P, here chosen), Tonkin.

Small subherbaceous climber, glabrous; dioecious. Leaves 3-foliolate, slightly carnose but not wrinkled on drying, $8-16 \mathrm{~cm}$ diam., glands absent; petiole c. $1 \mathrm{~cm}$ long; leaflets ovate-oblong, $6-10$ by $4-5 \mathrm{~cm}$, base attenuate into petiolule, apex acute(-acuminate), minutely acuminate, midvein stout, pale, nerves 3 or 4 pairs; petiolules $5(-10) \mathrm{mm}$ long. Male inflorescences lax, delicate, widely branched panicles, $13-20$ by $10-15 \mathrm{~cm}$, puberulous, terminal racemes condensed with (1-)2-7 flowers; bracts linear, c. $1 \mathrm{~mm}$ long, subcaducous. Male flowers: pedicel 1.5-2 mm long; perianth almost glabrous, very minutely papillose, $2-2.5 \mathrm{~mm}$ diam., receptacle less than $1 \mathrm{~mm}$ wide; sepals resembling petals, \pm obovate, minutely mucronate, c. 1.2 by $1 \mathrm{~mm}$; petals slightly longer, the midvein at base adaxially passing into raised membranes alternating with stamens. Filaments c. $0.6 \mathrm{~mm}$ long; anthers subglobose, c. $0.2 \mathrm{~mm}$ diameter. Female 


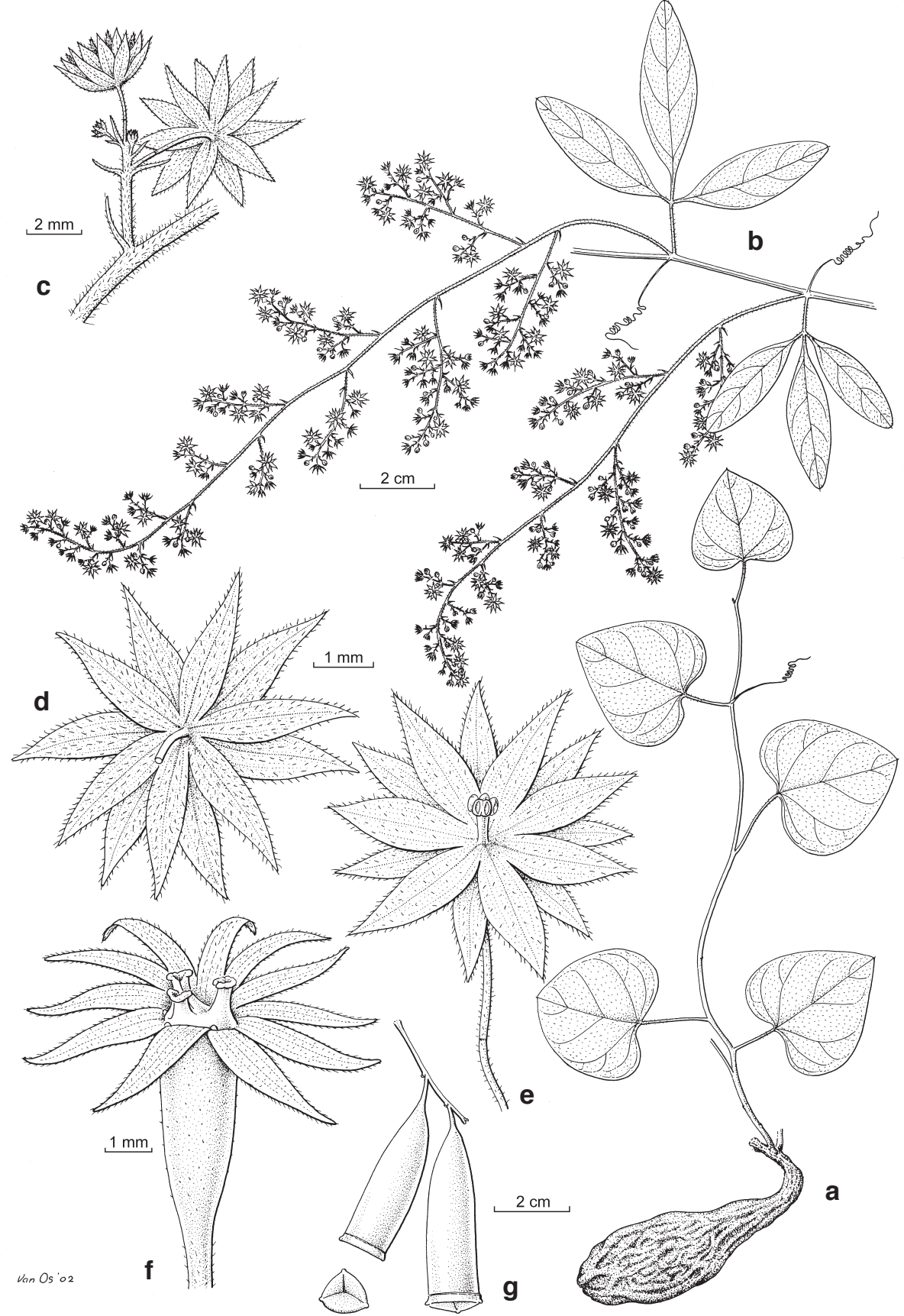

Fig. 2. Neoalsomitra angustipetala (Craib) Hutch. a. Sprouted tuber, note simple first leaves; b. male inflorescence on twig, note 3-foliolate leaves (leaves on non-flowering shoots usually 5 -foliolate); c. detail of male inflorescence; d, e. male flowers; f. female flower; g. fruit (a: De Wilde \& Duyfjes 22268; b-e: Maxwell 93-1047; f, g: Pooma et al. 3037). 
inflorescences (fruiting): paniculate, $10-18 \mathrm{~cm}$ long. Female flowers not known. Capsules 2-10 per infructescence; capsule subcylindrical, $5.5-6 \mathrm{~cm}$ long, base acute, apex truncate, c. $1.5 \mathrm{~cm}$ wide, glabrous; fruiting pedicel c. $10 \mathrm{~mm}$ long, glabrescent. Seeds c. 15 , subtriangular, c. 10 by $7 \mathrm{~mm}$, for c. $4 \mathrm{~mm}$ narrowed at base, apex long two-horned, faces densely verrucose, wing $10-13$ by $7 \mathrm{~mm}$.

Distribution - Vietnam: Tonkin; known only from 2 collections.

Habitat \& Ecology - In the mountains. Flowering: October; fruiting: November.

\section{Neoalsomitra capricornica (F. Muell.) Hutch. - Fig. 11}

Neoalsomitra capricornica (F. Muell.) Hutch. (1942) 99; I. Telford (1982) 163, f. 36 E-H, map 183. - Alsomitra capricornica F. Muell. (1870) 61; Cogn. (1881) 929; (1916) 12. - Type: P. O'Shanesy 1063 (MEL, not seen), E Queensland.

Small little-branched herbaceous climber, sparsely glandular-pilose, glabrescent; monoecious; annual(?). Leaves simple; petiole $2(-3) \mathrm{cm}$ long; blade membranous, broadly ovate, $4-8 \mathrm{~cm}$ diam., shallowly or deeply $3-5$-lobed, minutely mucronate, margin coarsely irregularly widely dentate; glands not known; green on drying. Inflorescences fragile, largely with male flowers, rather few-flowered, $3-15 \mathrm{~cm}$ long (including 2-5 $\mathrm{cm}$ long peduncle), male flowers in terminal and few lateral racemes, and at node of basal branch with a solitary female flower (always?); bracts lanceolate, less than $1 \mathrm{~mm}$ long. Male flowers: pedicel 2-6 mm long, (sub)glabrous or glandular hairy; perianth \pm bowl-shaped; receptacle minute; sepals oblong or lanceolate, $0.8-1$ by c. $0.4 \mathrm{~mm}$, acute; petals (ob)ovate, $1.5-2$ by c. $1.2 \mathrm{~mm}$, apex (abruptly) acute-acuminate, abaxially glabrous, adaxially finely glandular hairy. Filaments c. $0.7 \mathrm{~mm}$ long, connate for c. $0.6 \mathrm{~mm}$ into a slender column, glabrous; anthers broad-ellipsoid, c. $0.3 \mathrm{~mm}$ diam., without dark point adaxially. Female flowers: pedicel c. $4 \mathrm{~mm}$ long, subglabrous; ovary obconical, c. $3 \mathrm{~mm}$ long, sparsely pilose; sepals minute; petals elliptic, c. 1.5 $\mathrm{mm}$ long; styles including stigma c. $1 \mathrm{~mm}$ long, stigma \pm frondose. Capsule solitary on c. $3 \mathrm{~cm}$ long peduncle of otherwise male-flowered panicle; capsule $2-2.5(-3.5) \mathrm{cm}$ long, $0.9-1.2 \mathrm{~cm}$ wide, base rounded, sparsely roughly glandular pilose or setulose, valves glabrous; fruiting pedicel c. $10 \mathrm{~mm}$ long, pilose. Seeds rather many, obovate, (4-) 6 by $4-5 \mathrm{~mm}$, narrowed at base, margin few lobed-tuberculate towards apex, faces \pm finely warty, wing $8-10$ by $4 \mathrm{~mm}$.

Distribution - Australia (NE \& E Queensland).

Habitat \& Ecology - Climber in coastal forest. Flowering and fruiting: March and April.

Note - A richly flowering collection, apparently not seen for Flora of Australia (Telford, 1982), is Dietrich 1463, collected at Rockhampton around 1864-1866 (HBG, L).

\section{Neoalsomitra clavigera (Wall.) Hutch. - Fig. 1c}

Neoalsomitra clavigera (Wall.) Hutch. (1942) 101; C. Jeffrey (1980) 3; S.K. Chen (1986) 101, f. 32, 5-6. - Zanonia clavigera Wall. (1831a) 3725, nom. nud.; (1831b) 28, pl. 133. - Alsomitra clavigera (Wall.) M. Roem. (1846) 118; C.B. Clarke (1879) 634; Cogn. (1881) 931; (1916) 16. - Type: Wallich 3725A (lecto, excluding male inflorescence and seeds, K-Wall., here chosen), Sylhet (Bangladesh). 
Zanonia integerrima Wall. (1831a), nom. nud. (Wallich 3725B, K-Wall.).

Melothria trifoliolata F. Muell. (1866) 181. - Alsomitra trifoliolata (F. Muell.) K. Schum. (1898) 155; Cogn. (1916) 15. - Neoalsomitra trifoliolata (F. Muell.) Hutch. (1942) 100; I. Telford (1982) 165. - Alsomitra hookeri F. Muell. (1868) 188, nom. illeg.; (1877) 107 (not seen); Cogn. (1881) 933. - Zanonia hookeri F. Muell. (1882) 76, nom. illeg. - Type: J. Dallachy? in herb. F. Mueller s.n. (iso L, barcode L1623), Australia (Rockingham Bay).

Zanonia stephensiana F. Muell. (1874) 181. - Alsomitra stephensiana (F. Muell.) Cogn. (1881) 934; (1916) 17. - Neoalsomitra stephensiana (F. Muell.) Hutch. (1942) 102. - Type: W. Hill s.n. (ex F. v. Mueller, herbarium unknown, not seen), eastern Australia (Barnard Is.).

Alsomitra clavigera (Wall.) M. Roem. var. hookeri C.B. Clarke (1879) 635. - Type: Hook.f. s.n. (K), India (Khasia); a monstrum with non-alate seeds.

Alsomitra beccariana Cogn. (1881) 932. - Neoalsomitra beccariana (Cogn.) Hutch. (1942) 101. - Type: Beccari s.n. (holo FI; iso BR), Key Is.

Gynostemma integrifoliola Cogn. (1881) 916. - Alsomitra integrifoliola (Cogn.) Hayata (1911) 121. - Neoalsomitra integrifoliola (Cogn.) Hutch. (1942) 99; Merr. \& L.M. Perry (1949) 56; M. Jacobs (1954) 622; S.K. Chen (1986) 99, f. 32, 1-5; (1995) 279, f. 71, 3-5; Keraudren (1975) 12. - Lectotype (Keraudren, 1975): Cuming 517 (holo K; iso L, P), Philippines.

Alsomitra pubigera Prain (1898) 292; Cogn. (1916) 17. - Neoalsomitra pubigera (Prain) Hutch. (1942) 99; Chakrav. (1959) 197. - Type: Mokim (King's Coll.) s.n. (lecto, fruit, CAL, not seen; iso $\mathrm{K}$; here chosen), Burma (Kachin hills), Jan. 1898.

Gynostemma elongatum Merr. (1908) 267. - Hemsleya elongata (Merr.) Cogn. (1916) 26. - Type: FB (Curran) $5474 I$ ( $\mathrm{B} \dagger$; duplicates not seen), Philippines (Luzon).

Hemsleya henryi Cogn. (1916) 26. - Type: Henry 13420 (B†; duplicates not seen), Yunnan.

Alsomitra muelleri Cogn. (1887) 363; (1916) 15. - Neoalsomitra muelleri (Cogn.) Hutch. (1942) 100. - Type: Armit s.n. (herbarium unknown, not seen), Papua New Guinea.

Alsomitra rotundifolia Cogn. (1916) 13. - Neoalsomitra rotundifolia (Cogn.) Hutch. (1942) 100; Peekel (1984) 541, f. 863 (2). - Type: Peekel 471 (B †), Papua New Guinea; neotype here chosen: drawing f. 863 (2) in Peekel (1984).

Alsomitra pubescens Merr. (1918) 64. - Neoalsomitra pubescens (Merr.) Hutch. (1942) 101. - Type: FB (Mabesa) $26346(\dagger)$, Philippines.

Alsomitra tonkinensis Gagnep. (1918) 372; (1921) 1088. - Neoalsomitra tonkinensis (Gagnep.) Hutch. (1942) 100. - Type: Balansa 4024 (lecto P, here chosen), Tonkin.

Alsomitra pubigera Prain var. glauca Craib (1931) 768. - Type: Curtis 2504 (not seen), Langkawi Island.

Alsomitra schefferiana auct. non Cogn.: Peekel (1984) 541, f. 863 (1), based on Peekel 328 (382) (B十); Cogn. (1916) 15, p.p., f. 3A-H; Harms (1925) 152.

Herbaceous or subwoody climber to $12 \mathrm{~m}$ tall, pubescent or (nearly) glabrous all over; dioecious. Leaves 3-5-foliolate (i.e. the blade is primarily 3-foliolate and the lateral ones not divided or divided into 2 leaflets, the petiolule of the outer ones inserted on the petiolule of the inner), membranous, (5-) $10-20 \mathrm{~cm}$ across, glands 1 or 2, usually towards the base of the outer margin of the outer leaflets, flat, 1-3 mm diam., blackish on drying; petiole $0.5-3(-5) \mathrm{cm}$ long; leaflets ovate or elliptic(-oblong), to $12(-15)$ by $5(-8) \mathrm{cm}$, base (obtuse or) attenuate, apex obtuse or acute, 1-2 mm mucronate, petiolules 0.4-2 cm long, midvein distinct, lateral veins 4-7 per side. Male inflorescences broadly paniculate, axillary, $10-30 \mathrm{~cm}$ long, peduncle $1.5-4 \mathrm{~cm}$ long, branches (glandular-) pubescent or subglabrous, bracts linear, minute $0.5-2 \mathrm{~mm}$ long, the basal ones larger and 3(-5)-foliolate, to $1 \mathrm{~cm}$ long, flowers up to 5 (sub)fascicled, in condensed terminal racemes. Male flowers: pedicel slender, 5-10 mm long, (glandular-)pubescent or subglabrous; bud ovoid; perianth 5-8 mm diam., receptacle shallow, 1.5-2 mm diam., sometimes 5-saccate below sepals; sepals ovate-oblong, acuminate, c. $2 \mathrm{~mm}$ long; petals ovate, subobtuse or acute, $2.5-3$ by (1.5-) $2 \mathrm{~mm}$, glabrous or puberulous. 
Filaments free, c. $0.5 \mathrm{~mm}$ long; anthers less than $0.5 \mathrm{~mm}$ diam. Female inflorescences paniculate, $2-10 \mathrm{~cm}$ long, up to 10 -flowered. Female flowers: pedicel c. $10 \mathrm{~mm}$, ovary subcylindrical, 7-8(-10) $\mathrm{mm}$ long, finely pubescent, styles short, stigma not lobulate. Infructescence one- or several-fruited. Capsule $4-8 \mathrm{~cm}$ long, glabrous or pubescent, base narrowed or rounded, at apex $1.2-2.5(-3) \mathrm{cm}$ wide; fruiting pedicel $10-20 \mathrm{~mm}$ long. Seeds many, \pm unequal-sided star-shaped, $6-11$ by $5-8 \mathrm{~mm}$, margin of $5-7$ coarse acute or blunt teeth, faces low tuberculate, wing 14-27 $\mathrm{mm}$ long to $8 \mathrm{~mm}$ wide.

Distribution - NE India, Bhutan, Myanmar, S China (Yunnan, Hainan), Taiwan, Laos, Cambodia, Vietnam, Thailand, through Langkawi Is., N Sumatra, Philippines, E to NE Australia (Queensland) and the Pacific (Solomon Is., E to Fiji). (Not in Peninsular Malaysia, C \& S Sumatra, Java, Borneo.)

Habitat \& Ecology - Shaded and open places in primary evergreen montane forest and evergreen seasonal forest along streams, clayey soils on limestone and granite bedrock, altitude $200-1300 \mathrm{~m}$.

Notes - 1. A polymorphic species, varying in hairiness, number and shape of leaflets, and size and shape of fruit. The fruit varies in length from 4 to $8 \mathrm{~cm}$ and may be (sub) glabrous or hairy including densely pubescent (N. pubigera, from Myanmar). Fruit size varies especially in NE India and New Guinea, where large-fruited as well as smaller-fruited specimens have been collected; for example fruits from New Guinea vary from 4 to $8 \mathrm{~cm}$ long, including fruits of $\mathrm{c} .4 \mathrm{~cm}$ long with a comparatively broad apex, to nearly $3 \mathrm{~cm}$ diameter, and with a broad rounded base. The largest fruits contain the largest seeds. Alsomitra pubigera Prain var. glauca Craib is a limestone form with somewhat succulent leaves with rather short petioles.

2. The typification of the here accepted oldest name is complicated and needs explanation. Wallich's description (1831b) refers to number 3725 of his List (1831a). In the Wallich Herbarium (K-Wall.) are two sheets of 3725: 3725A \& 3725B; the leafy shoots on both sheets belong to one taxon. However, 3725A, in fruit, bears the name Zanonia clavigera Wall., while $3725 B$, male flowering, bears the name Zanonia integerrima Wall.; the latter name remains a nomen nudum. Sheet $3725 \mathrm{~A}$ comprises, on close examination, a mixture of 3 elements: 1) a long, curved shoot, bearing immature and mature fruits $4-5 \mathrm{~cm}$ long; 2 ) a short leafy fragment with a male inflorescence (apparently identical with the material on 3725B); and 3) three seeds of Zanonia indica (already remarked so by Clarke, 1879). Wallich's protologue (1831b) consists of a description of the leafy shoot and of the fruit and seeds, but the description of the fruit obviously concerns the fruit from which the seeds were taken, hence Zanonia indica, though this fruit is not present on sheet $3725 \mathrm{~A}$. The fruit was described as being broad and c. 3 inches $(7-8 \mathrm{~cm})$ long, whereas the fruits on $3725 \mathrm{~A}$ are much smaller, and rather narrow. By the exclusion of Wallich's material of the seeds (and hence also the corresponding fruit, described by him in the protologue) we herewith reconfirm and choose again the element of the leafy shoot with attached fruits on sheet $3725 \mathrm{~A}$ (K-Wall.) as lectotype of Zanonia clavigera Wall., as was already indirectly chosen by Clarke (1879).

3. Cogniaux's figure 3A-H (1916), apparently from Peekel 328 (B†), was erroneously taken for the male flowers of Alsomitra schefferiana, but represents N. clavigera; Peekel 328 was also depicted in Peekel (1984). The small apical appendage of the anther obviously is exaggerated in the drawing, as normally this is much smaller or absent. 
5. Neoalsomitra hederifolia (Decne.) W.J. de Wilde \& Duyfjes, comb. nov.

- Fig. 1i, 3

Sicyos hederifolius Decne. (1834) 450; Walp. (1843) 204; M. Roem. (1846) 104; Span. (1841) 206; Miq. (1856) 682, 'hederaefolius'. - Gynostemma ? hederifolia (Decne.) Cogn. (1881) 916, 'hederaefolia'; M. Jacobs (1954) 617 (excluding material Hort. Bot. Bog. sub XVIII A 45); Steenis (1956) 192, f. 1a. - Type: Anonymous (3 sheets, see note) (531, barcode P218602, lecto $\mathrm{P}$, here chosen), Timor.

Zanonia timorana Span. (1841) 205, Icon. 55 (plate not found); Walp. (1843) 194, 'timorensis'; Miq. (1856) 683. - Alsomitra timorana (Span.) M. Roem. (1846) 117; Cogn. (1881) 935; (1916) 13. - Neoalsomitra timorana (Span.) Hutch. (1942) 98. - Neotype (here designated, see note): De Voogd 2323, male fl. (holo L; iso BO, K, SING), Timor.

Gynostemma spec. C. de Voogd (1936) 71, f. 8, photo of habit; Woerden (1940) 6, f. 7, photo of thickened stem base.

Low or medium climber, densely or sparsely glandular-pubescent all over (except flowers), hairs $0.5-2 \mathrm{~mm}$ long; stem at base to $1 \mathrm{~cm}$ thick; dioecious; perennial, growing from a supra-terranean tuber to 30 by $15 \mathrm{~cm}$ and c. $2.5 \mathrm{~kg}$ in weight. Leaves simple, brown on drying; petiole $1.5-3 \mathrm{~cm}$ long; blade entire or shallowly 3(-5)-lobed, membranous, broadly ovate or circular in outline, $5-6$ by $4-7.5 \mathrm{~cm}$, base deeply cordate, apices acute-acuminate, 1(-2) $\mathrm{mm}$ mucronate, margin entire or coarsely remotely dentate, sparsely or densely (setose) hairy, especially so on margin and abaxially on nerves; nerves 5-palmate, pale; glands absent. Male inflorescences paniculate, pu-

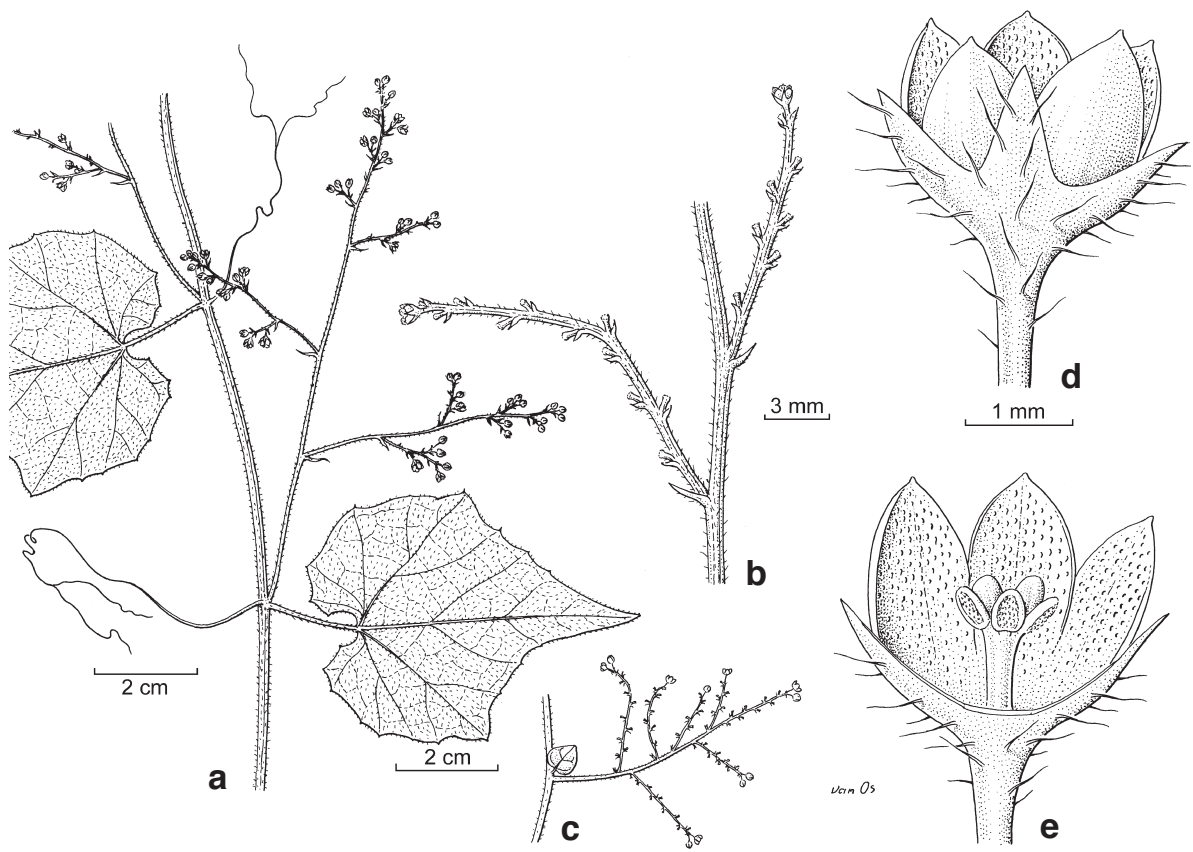

Fig. 3.Neoalsomitra hederifolia (Decne.) W.J. de Wilde \& Duyfjes. a. Habit with male inflorescence; b. detail of male inflorescence; c. portion of male inflorescence; d, e. male flowers (a, b, d, e: Backer 26948; c: 'Decaisne' P00218601, syntype). 
bescent, situated occasionally close to the base of the plant, once or twice branched, $5-17(-32) \mathrm{cm}$ long including 1-2.5 cm long peduncle, ultimate branches raceme-like, 1-4 cm long, 5-10(-15)-flowered, with bracts and basal portion of pedicel (c. $1 \mathrm{~mm}$ long) persistent; bracts minute, oblong, 0.5-1 mm long, lower bracts in the larger twice branched, inflorescences leafy, 1-1.5 cm diam. Male flowers solitary, (sub)glabrous; pedicel 3-4 $\mathrm{mm}$ long, articulate at c. $1 \mathrm{~mm}$ from the base; bud subglobose; perianth at anthesis bowl-shaped; receptacle shallowly bowl-shaped, $0.4-0.5$ by c. $1.5 \mathrm{~mm}$; sepals long-triangular, c. $1 \mathrm{~mm}$ long, with out-curved apiculum; petals broadly obovate or subcircular, c. $1.5 \mathrm{~mm}$ long, papillose adaxially, very minutely mucronate. Filaments (0.7-) $1 \mathrm{~mm}$ long, either completely or for $2 / 3$ fused (column hollow); anthers elliptic or subcircular, c. $0.5 \mathrm{~mm}$ long, adaxially with or without a faint brown spot. Female inflorescences and flowers not known. Infructescences (sub)racemose, 3-5-fruited or a fruit solitary on the leafy node of lateral shoots. Capsule brittle, glabrescent, $2.5-3 \mathrm{~cm}$ long, at apex (0.8-) $1 \mathrm{~cm}$ wide, base narrowly rounded, perianth scar (rim) at c. $2.5 \mathrm{~mm}$ distant from the flat apex; fruiting pedicel 7-10 $\mathrm{mm}$ long, glabrous with some vestigial minute hairs. Seeds $15-20$, obovate with narrowed base, c. 6 by $4.5 \mathrm{~mm}$, dark brown, margin coarsely 5-toothed, faces coarsely few-tubercled, wing 7 by $2.5 \mathrm{~mm}$.

Distribution - Indonesia, known from 5 collections: Kangean, E of Madura, Backer 26948, male (BO), filaments completely fused; Pulau Semau, near Timor, De Voogd 2323, male (BO, K, L, SING), filaments fused for 2/3; Timor, Anonymous s.n., male, 3 sheets (in Herb. Decaisne, P), filaments completely fused.; Anonymous s.n. fruits (P); Spanoghe s.n., specimens not found.

Habitat \& Ecology - Lowland savannah and dry forest in monsoon climate on limestone; 0-200 m altitude. Flowering: March (Kangean) and November (Timor).

Notes -1 . The three anonymous sheets with male flowers in P, syntypes of Sicyos hederifolia, were collected around 1801-1821, either by Sautier, Riedlé, Quichenot, or by Gaudichaud; see Van Steenis-Kruseman (1950), and the introduction to Decaisne's enumeration (1834).

2. The infructescences and fruits of Sicyos hederifolia are known only from an anonymous single collection in P, a leafless specimen annotated Zanonia indica L., Timor, apparently collected in the same period as the type of S. hederifolius. Its assignment to $N$. hederifolia is not fully certain, but the old, dead twigs with leaf scars and tendrils agree, and the fruits and seed (one single seed only is preserved, Fig. 1i) differ from the fruits and seeds of the other Neoalsomitras from Timor: N. sarcophylla differs in seed and $N$. schefferiana subsp. podagrica differs in fruiting pedicel c. $5 \mathrm{~mm}$ long against c. $10 \mathrm{~mm}$ long in $N$. hederifolia.

3. Jacobs (1954) cites a note by Van Steenis on living flowering material cultivated in Bogor, about 1939, not preserved or apparently lost, obviously belonging to N. hederifolia.

4. It is not fully certain whether the photo of the tuber in Van Woerden (1940) represents $N$. hederifolia, as no voucher specimen was collected.

5. For Zanonia timorana Span. a neotype is designated as the type Spanoghe s.n., from Timor, could not be found. According to Van Steenis-Kruseman (1950), Spanoghe specimens and icones are in L, but are not extant there. Spanoghe (1841) described male and female flowers and fruits. 
6. Neoalsomitra pilosa W.J. de Wilde \& Duyfjes, spec.nov. - Fig. 1j

Neoalsomitra capricornica F. Muell. similis, fructuum pilis densioribus longioribus (3-4 $\mathrm{mm}$ ) obsito differt. - Typus: Carr 12477 (holo CANB; iso BM, K, L, SING), fruits, E Papua New Guinea.

Herbaceous climber, a few metres long, sparsely soft-woolly grey glandular-hairy; annual?; monoecious. Leaves simple, membranous, blackish on drying, sparsely villous; petiole $1-1.5 \mathrm{~cm}$ long; blade entire or shallowly (faintly) 3-5-lobed, \pm ovate, $4-7.5$ by $3.5-7 \mathrm{~cm}$, base broadly cordate, apex rather long acute-acuminate, minutely mucronate, margin entire, ad- and abaxially villose; glands absent. Inflorescences glandular hairy, to $10 \mathrm{~cm}$ long (including 2-6 cm long peduncle), with few (uni)lateral 10-20-flowered male racemes, and with 1 (or 2 or 3 ) solitary female flowers (fruit) at the nodes of the lower branch(es), occasionally co-axillary with the panicle an additional male raceme; bracts lanceolate, c. $1 \mathrm{~mm}$ long, \pm caducous. Male flowers: pedicel 1.5-2 mm long, sparsely hairy; perianth \pm bowl-shaped; receptacle shallowly bowl-shaped, 0.7 (-1) $\mathrm{mm}$ wide; sepals \pm long-triangular, c. $1 \mathrm{~mm}$ long, sparsely hairy; petals (ovate-)elliptic, c. $1.5 \mathrm{~mm}$ long, glabrous, at apex with minute papillose mucro. Filaments united into c. $0.5 \mathrm{~mm}$ long column; anthers 1-thecous, broadly ellipsoid, c. $0.3 \mathrm{~mm}$ long, abaxially with minute dark blotch. Female flowers not known (ovary hairy). Capsules 1(-3) per infructescence (in old otherwise male-flowered inflorescence); capsule (2.5-)3-3.5 by $1-1.3 \mathrm{~cm}$, sparsely whitish villous, hairs glandular, $3-4 \mathrm{~mm}$ long, base (narrowly) rounded, apex truncate, with 2-3 mm long stylar processes; fruiting pedicel $4-8 \mathrm{~mm}$ long. Seeds $15-20$, obovate, narrowed at base, 6-7 by (4-)5 mm including double 6-8-toothed margin, faces ribbed towards margin, nearly smooth in the centre, wing c. 8 by $4 \mathrm{~mm}$.

Distribution - SE Papua New Guinea, in the mountains near Port Moresby; known only from 2 collections: Carr 12477 (male fl., fr.) and Carr 15873 (male fl., immat. fr.).

Habitat \& Ecology - Open places in woods on steep hillsides; 400-1500 m altitude. Flowering and fruiting: March to June.

Note - This species is close to $N$. capricornica, which differs in drying colour green, leaf shape and more coarsely hairy capsules.

\section{Neoalsomitra plena (Craib) Hutch. - Fig. If}

Neoalsomitra plena (Craib) Hutch. (1942) 768. - Alsomitra plena Craib (1930) 408; (1931) 768.

- Type: Kerr16191 (lecto K, here chosen, male), Thailand (Prachuap, South-western Prov.).

Climbing herb 1-5 m tall, finely glandular-hairy; dioecious; annual or biennial. Leaves simple (but shallowly or deeply 3-5-lobed, or subfoliolate), or 3-5-foliolate; petiole $0.5-3 \mathrm{~cm}$ long; blade membranous, $2-13 \mathrm{~cm}$ diam., glands absent; leaflets ovate or elliptic-oblong, base attenuate or rounded, apex acute, 1-3 mm mucronate, lateral nerves 3-5 per side, petiolules 3-10 mm long. Male inflorescences paniculate, usually narrow, little-branched or raceme-like, 5-10 $(-15) \mathrm{cm}$ long, branches raceme-like, puberulous, peduncle short; bracts linear, 1-2(-3) mm long, \pm caducous. Male flowers solitary or 2 per bract; pedicel (4-)5-12 mm long, glandular-pubescent; buds at apex 5-toothed by \pm spreading apices of sepals; corolla subrotate, $6-8 \mathrm{~mm}$ diam.; receptacle shallow, 
c. $1.5 \mathrm{~mm}$ diam.; sepals narrowly triangular, acuminate, $1.5-2 \mathrm{~mm}$ long, puberulous; petals ovate(-oblong), acute-acuminate, $2.5-3(-4)$ by c. $2.5 \mathrm{~mm}$, with midvein at base raised adaxially, subglabrous. Filaments free, out- and recurved, 0.5-0.7 mm long; anthers less than $0.5 \mathrm{~mm}$ long, inserted on broadened apex of filaments. Female inflorescences 1- or few-flowered. Female flowers: pedicel 3-7 mm long, faintly articulate, puberulous; ovary 4-5 by c. $1 \mathrm{~mm}$, glabrous; tepals as in male; staminodes \pm fleshy, c. $0.2 \mathrm{~mm}$ long (see note); styles c. $0.6 \mathrm{~mm}$ long, stigma $0.5 \mathrm{~mm}$ long. Capsules solitary (or 2 or 3 on short shoot), capsule $2.5-3$ by $0.6-0.9 \mathrm{~cm}$, glabrous, base \pm rounded, apex truncate; fruiting pedicel 5(-10) mm long. Seeds $15-20$, light brown to nearly black, ellipsoid with abruptly narrowed base, $4-5$ by $2.5-3.5 \mathrm{~mm}$, margin finely or coarsely undulate, faces smooth or faintly irregular-warty, wing nearly all around seed but much extending to one side, c. 8 by $4-5 \mathrm{~mm}$.

Distribution - Endemic to Thailand: Northern, Eastern (Nakhon Ratchasima), South-Western, Central, Peninsular (Surat Thani).

Habitat \& Ecology - Scrub and rocky places on limestone; altitudes 10-580 m. Flowering and fruiting: May to December.

Note - The staminodes, alternating with the petals in the female flowers, are unique for the genus in this species. They were described by Craib (1930), as half as long as the sepals, but in our material seen (Pooma et al. 2102) they are only $0.2 \mathrm{~mm}$ long. Craib (1930) described the fruit as $4 \mathrm{~cm}$ long; in several collections we measured $2.5-3 \mathrm{~cm}$ long.

\section{Neoalsomitra sarcophylla (Wall.) Hutch. - Fig. 1b}

Neoalsomitra sarcophylla (Wall.) Hutch. (1942) 100; Chakrav. (1959) 194; Keraudren (1975) 9, pl. 1.(p.p., excl. Neoalsomitra balansae). - Zanonia sarcophylla Wall. (1831a) 3724, nom. nud.; (1831b) 28, t. 133. - Alsomitra sarcophylla M. Roem. (1846) 118; Cogn. (1881) 929; (1916) 13; Craib (1931) 769; P.H. Hô (1991) 713, f. 1977. - Type: Wallich 3724B (lecto K-Wall., here chosen, fr.), Burma.

Alsomitra philippinensis Cogn. (1916) 15. - Neoalsomitra philippinensis (Cogn.) Hutch. (1942) 100. - Type: Copeland 255 (B†), Philippines, Luzon.

Liana 3-7 m, glabrous; perennial from woody rootstock; dioecious. Leaves 3-foliolate, fleshy-leathery, wrinkled on drying, 5-20 cm diam., glands absent; petiole $0.5-1 \mathrm{~cm}$ long; leaflets (broadly) ovate-elliptic to oblong-lanceolate, to 12 by $6 \mathrm{~cm}$, base rounded or \pm narrowed, apex (narrowly) rounded, minutely mucronate, basal nerves 3-5, curving towards apex, mostly indistinct; petiolules $0.2-0.5(-1) \mathrm{cm}$ long, after abscission leaving raised flat scars. Tendrils often with terminal adhesive pads. Male inflorescences paniculate, little or much branched, sometimes branched from the base, 10-20(-30) $\mathrm{cm}$ long, pendent, glabrous; bracts linear, $1 \mathrm{~mm}$ long or less. Female inflorescences paniculate or \pm raceme-like, $5-10 \mathrm{~cm}$ long. Male flowers often to 3 sub-fascicled, pedicel 2-5 mm long; perianth subrotate, c. $5 \mathrm{~mm}$ diam., glabrous or minutely papillose; receptacle flattish, faintly 5 -saccate, c. $1 \mathrm{~mm}$ diam.; sepals lanceolate, c. $2.5 \mathrm{~mm}$ long, acuminate; petals (ob)ovate, c. 3 by $1.5 \mathrm{~mm}$, apex acuminate, midvein distinctly raised in lower portion, forming dissepiments between the stamens. Filaments free, spreading, c. $1 \mathrm{~mm}$ long; anthers less than $0.5 \mathrm{~mm}$ long. Female flowers: ovary narrow, c. 8 by $1 \mathrm{~mm}$, glabrous; staminodes $0.2-0.5 \mathrm{~mm}$ long; styles short, broad at base, stigma \pm lobulate-dentate; style and stigma together c. $1 \mathrm{~mm}$ long. Infructescences pendent, 
5-10 cm long, with 5-10(-20) capsules. Capsule much narrowed to the base, glabrous, $3(-4) \mathrm{cm}$ long, apex truncate, $8(-10) \mathrm{mm}$ wide; fruiting pedicel slender, $10(-15) \mathrm{mm}$ long. Seeds $12-15$, sub-triangular, $6-7$ by 3-4 mm, 2-horned at apex, margined, edge smooth or verrucose, faces finely verrucose, wing suberect, $8-10$ by $4 \mathrm{~mm}$.

Distribution - Myanmar, Thailand, Laos, Cambodia, Vietnam, Langkawi Is., rare and scattered in E Malesia: Philippines (Luzon, Palawan), Celebes (Central, SW, Kabaena Is.), Timor. Sometimes cultivated in botanical gardens.

Habitat \& Ecology - Mixed, (partly) deciduous evergreen lowland and montane forest, on basalt and granite bedrock and limestone; altitude 10-850 m. In SE Asia: flowering: November to January; fruiting: December to March; in E Malesia: flowering: March to September.

Note - In Teijsmann 19765 (BR), Timor, the seeds lack the two horns; it is the only known collection with seeds from E Malesia.

\section{Neoalsomitra schefferiana (Cogn.) Hutch. - Fig. 1g, h}

Neoalsomitra schefferiana (Cogn.) Hutch. (1942) 101, (excl. Peekel $328(\mathrm{~B} \dagger)=$ Neoalsomitra clavigera.) - Alsomitra schefferiana Cogn. (1881) 932; (1916) 16, excl. descr. fl. masc. sec Peekel 328 et excl. f. 3A-H. - Type: Teijsmann 11854, sheet 1 of 4 (holo BO; iso BO (3 sheets), L), Celebes, Pangkadjena.

Alsomitra schefferiana Cogn. var. minor Cogn. (1881) 933; (1916) 16. - Type: Teijsmann s.n. (holo BO, not seen), SW Celebes, Pangkadjena.

For further references see under the subspecies.

Perennial climber to $8(-30) \mathrm{m}$ long, with one or few green stems somewhat fleshywoody at base, either slightly thickened, or base swollen, flask- or spindle-shaped, stem with \pm hard green thorns $1-2(-4) \mathrm{cm}$ long up to 3(-5) $\mathrm{m}$ from the ground, apical shoots puberulous, glabrescent, finely grooved, with raised leaf scars; dioecious. Leaves ( simple or) 3- or 5-foliolate; petiole $2-5 \mathrm{~cm}$ long; blade membranous (slightly fleshy when fresh), green on drying, 5-15(-20) cm diam.; glands absent; petiolules 0.3-2 $\mathrm{cm}$ long, those of outermost leaflets in 5-foliolate leaves inserted on those of the next leaflets; leaflets elliptic or (ob)ovate, apex roundish or acute, minutely acuminate, the middle leaflet largest, to $11(-15)$ by $7(-10) \mathrm{cm}$. Tendrils on innovations, mostly caducous, and on apical shoots. Male inflorescences paniculate, with numerous flowers, $8-20(-40) \mathrm{cm}$ long, once or twice branched, ultimate branches raceme-like, pubescent, hairs c. $1 \mathrm{~mm}$ long; bracts minute, c. $1 \mathrm{~mm}$ long, pubescent (lower bracts 3-foliolate, larger). Male flowers: pedicel c. $1.5 \mathrm{~mm}$ long, glabrous; perianth rotate, $2.5-3.5 \mathrm{~mm}$ diam., sparsely pubescent; receptacle shallow, c. $1 \mathrm{~mm}$ wide; sepals ovate-acute, c. $0.5 \mathrm{~mm}$ long; petals broadly ovate-acute, c. $1 \mathrm{~mm}$ long. Filaments glabrous, fused into a partly hollow column c. $0.75 \mathrm{~mm}$ long, free parts c. $0.25 \mathrm{~mm}$ long, anthers broadly ellipsoid, c. $0.25 \mathrm{~mm}$ long, dark spot not obvious. Female inflorescences: as in male, (widely) paniculate, $10-30 \mathrm{~cm}$ long, flowers ultimately in racemes. Female flowers: see under subsp. podagrica. Capsule many per infructescence; capsule $1.5-2.5 \mathrm{~cm}$ long, $0.7-0.9 \mathrm{~cm}$ wide, pubescent, glabrescent, base \pm attenuate or rounded, apex truncate with minute style-remnants; fruiting pedicel 2-7 mm long, glabrous or pubescent. Seeds c. 15 , obovate, $4-5$ by $3-3.5 \mathrm{~mm}$, base attenuate, finely or coarsely rugulose-warted, margin double 5-7-toothed or -tuberculate, wing 6-8 $\mathrm{mm}$ long. 
Distribution - E Malesia: SW Celebes, Moluccas, eastern Lesser Sunda Islands, and Irian Jaya: Vogelkop Peninsula; 2 subspecies.

Habitat \& Ecology — Limestone rocks and soil over limestone, dry seasonal areas; lowland. Flowering: February (Timor), May (Alor), June (Seram).

Uses - Used medicinally for its extremely bitter resin with strong haemolytic action in Timor; see Van Steenis (1956). In Vogelkop the people are afraid to be hurt by the thorns (Avé, oral comm.).

Notes - 1. Neoalsomitra schefferiana is characterized by its thorny stem base, 3- or 5-foliolate leaves, and stamens of which the filaments are c. 3/4 connate.

2 . The limited fertile material available suggests the existence of only one species, with 2 subspecies. The wild growing specimens as well as those cultivated in the greenhouse of both subspecies (which persistently refuse to flower in European greenhouses) are possibly distinct in the mode of swelling of the stem base; we did not see conspicuous stem thickening in our own Celebes specimens of subsp. schefferiana, and stem thickening was not mentioned for the remainder of the collections.

The two subspecies chiefly differ in shape of the thorny stem base and fruit size; the male perianths of a specimen from Seram (Kornassi 1433) are slightly longer than those from Timor. Because most collections are sterile and mostly the thorny base is not recorded, such specimens are tentatively assigned to subsp. schefferiana. Subsp. podagrica is regarded as confined to Timor and the nearby islands of Semau and Alor.

The thorns are obviously homologous with leaves, as was already noted by Van Steenis (1956). Occasionally the bases of withered tendrils may resemble thorns. In the collections from Vogelkop of subsp. schefferiana (Avé 4835) some thorns are minutely furcate at apex.

\section{KEY TO THE SUBSPECIES}

1a. Main stem at base not or hardly thickened, $2-3 \mathrm{~cm}$ thick. Leaves of (fertile) upper branches 3-foliolate. Capsules c. $2.5 \mathrm{~cm}$ long (material of var. minor not seen). - SW Celebes, Seram, Vogelkop Peninsula. . . . . . . . a. subsp. schefferiana

b. Main stem at base swollen, 5-10 cm thick. Leaves of (fertile) upper branches 3- or 5-foliolate. Capsules 1.5-2 cm long. - Timor, Alor Is.. . . b. bubsp. podagrica

a. subsp. schefferiana - Fig. $1 \mathrm{~g}$

Main stem base slender, 2-3 cm diam., thorns 1-2 cm long. Leaves 3-foliolate. Female flowers not known. Infructescences rather open, much branched, many-fruited, shorttomentose, $20-30 \mathrm{~cm}$ long. Capsules c. 2.5 by $0.7-0.9 \mathrm{~cm}$, base shortly attenuate, when old glabrescent except at the very base; fruiting pedicel 3-7 mm long, tomentose. Seeds ovate, $4.5-5$ by $3-3.5 \mathrm{~mm}$, faces densely sharply, rather finely tuberculate, margin finely crenulate, wing $6-7$ by c. $4 \mathrm{~mm}$.

Distribution - Known from one fruiting collection from SW Celebes (type); one male flowering specimen from Seram, and from sterile specimens from SW Celebes, and Vogelkop Peninsula. 
b. subsp. podagrica (Steenis) W.J. de Wilde \& Duyfjes, stat. nov. - Fig. 1h

Neoalsomitra podagrica Steenis (1956) 192,f. 1b, 2, nom. prov.; (1955) 171, f. 1; H. Jacobsen (1970)

267, t. 112, 1; E. Newton \& Njoroge (2002) 90,f. 13e. - Type: Pleyte s.n. (lecto L, here chosen), male, culta, Hort. Bot. Bogor II-0-X-6, Timor (see note 1), 6 May 1954.

Alsomitra spec. Woerden (1940) 6, f. 7, right hand photo.

Base of main stem(s) fleshy, thickened, flask- or spindle-shaped up to 100 by $10 \mathrm{~cm}$, sometimes with additional superposed thickened bases of lateral stems; thornes 1.5-5 $\mathrm{cm}$ long. Leaves: lower 3-foliolate, upper 3- or 5-foliolate. Female inflorescences paniculate, rather condensed, pubescent, the ultimate branches one-sided racemes with up-curved flowers; bracts minute. Female flowers: pedicel c. $1 \mathrm{~mm}$ long, glabrous; ovary tubular, terete, c. 3 by (1-) $1.5 \mathrm{~mm}$, pubescent; sepals hardly $1 \mathrm{~mm}$ long; petals c. 2 by $1.5 \mathrm{~mm}, \pm$ pubescent (some adaxially with minute appendages at base); styles including stigma c. $1 \mathrm{~mm}$ long. Fruits many per infructescence. Capsule almost glabrous, $1.5-2$ by $0.7-0.8 \mathrm{~cm}$, base narrowed or rounded; fruiting pedicel $2-5 \mathrm{~mm}$ long, almost glabrous. Seeds pear-shaped, $4-5$ by $3-3.5 \mathrm{~mm}$, faces coarsely tuberculate and with irregular radial crests, wings $6.5-8.5$ by $3.5-4.5 \mathrm{~mm}$.

Distribution - Eastern Lesser Sunda Islands: Alor Is., Semau Is., and Timor (according to Van Steenis (1956) throughout Timor).

Habitat \& Ecology - Lowland and hilly country on limestone.

Notes - 1. Subspecies podagrica was introduced by tubers from Timor (through the mediation of Mr de Voogd and Mr Koster, see also under N. hederifolia) about 1938-1940 into the Botanic Garden at Bogor and the private garden of Van Steenis, also Bogor. Around 1940 it was male flowering in the garden of Van Steenis and between 1954 and 1960, individual male and female plants were richly flowering and fruiting in the Botanic Garden, but since 1995 the subspecies is no longer extant there. In some European greenhouses the subspecies grows easily and is propagated by cuttings; however, it never flowers.

2. Although the subspecies seems widespread in Timor it is noteworthy that this conspicuous plant was not seen by the old French and Dutch collectors, who collected the pachypodous $N$. hederifolia (syn. N.timorana) several times. Anyway, in the wild, subsp. podagrica seems to flower or fruit at an unknown period, under a strong seasonal climate, but apparently not frequently.

3. This subspecies was already, though unnamed, pictured and described in a manuscript by Father Alberti de San Tomé about 1750, in Lisbon (as was discovered there by Mr Koster, postmaster at Kupang; see Van Steenis (1956), Van Steenis-Kruseman (1950) 298).

\section{Neoalsomitra schultzei (Cogn.) Hutch. - Fig. 1k}

Neoalsomitra schultzei (Cogn.) Hutch. (1942) 98; Merr. \& L.M. Perry (1949) 56. - Alsomitra schultzei Cogn. (1916) 12. - Type: Schultze 170 (B†), Papua New Guinea (Augusta River).

Slender small climber; subglabrous; monoecious; annual? Leaves simple, glabrous except for a few hairs near insertion of petiole; petiole $1-1.5 \mathrm{~cm}$ long, sparsely minutely pubescent; blade membranous, green on drying, ovate in outline, $3.5-7 \mathrm{~cm}$ diam., faintly to distinctly (3-)5-lobed (up to c. $2 / 3$ deep), base subtruncate or cordate, apex acute-acuminate, 1-2 mm mucronate as are lobe-apices, margin smooth or coarsely 
sinuate. Inflorescences glabrous, all or predominantly male-lowered, sometimes with a few female flowers co-axillary with lowermost branch(es), branches few, consisting of 5-10 male-flowered racemes; position of female flowers (from fruits) either mixed in otherwise male flowered panicle (see above) or solitary at leafy node; bracts oblong, 0.5-1 mm long, subpersistent. Male flowers: pedicel c. $1.5 \mathrm{~mm}$ long, the lower half persistent; perianth bowl-shaped; receptacle-tube $\mathrm{c}$. 1 by $1.5-2 \mathrm{~mm}$, the inside wholly thickened into an inconspicuous disc; sepals (long-)triangular, c. 0.8(-1) by $0.7 \mathrm{~mm}$, acute; petals ovate-broadly ellipsoid, minutely mucronate, dotted with glands. Filaments united for $2 / 3$ or completely united, c. $1 \mathrm{~mm}$ long; anthers ellipsoid, c. $0.6 \mathrm{~mm}$ long, adaxially without dark blotch. Female flowers not seen (ovary subclavate, 4-5 mm long, glabrous, corolla segments c. 2 mm long, see Cogniaux, 1916). Capsules $1(-6)$ per infructescence, solitary at leafy node, or peduncled; capsule $2.5-3 \mathrm{~cm}$ long, glabrous, base rounded, 10-12 mm wide at truncate apex; fruiting pedicel c. $10 \mathrm{~mm}$ long. Seeds $15-20$, obovate with narrowed base, $6-7$ by $4-5 \mathrm{~mm}$, margin $5-7$ coarsely dentate or tuberculate, faces finely warty, wing c. 9 by $4-5 \mathrm{~mm}$.

Distribution - Papua New Guinea, known from a few collections only (Sepik, lower Fly River, Central Prov.).

Habitat \& Ecology - Lowland; margins of monsoon forest, in reed swamps. Flowering and fruiting: April and October.

Notes -1 . The present description of $N$. schultzei, drawn from the collections Brass 8149 and Pullen 6847, is somewhat doubtful because the type, Schultze 170, is lost, but Cogniaux's protologue agrees very well. A designation of a neotype should wait for a good collection from the type locality, Sepik (Augusta River).

2. Neoalsomitra schultzii is distinct within the genus by a disc-like thickened receptacle. It forms together with $N$. capricornica, $N$. pilosa and $N$. hederifolia a group within Neoalsomitra. However, we have refrained from naming this group, as explained in the introduction.

\section{Neoalsomitra simplex (Craib) Hutch. - Fig. 1d, 4, 5}

Neoalsomitra simplex (Craib) Hutch. (1942) 98. - Alsomitra simplex Craib (1930) 409; (1931) 769.

- Type: Kerr 7524 (holo K; iso BK), Thailand.

Low- to medium-sized climber, subherbaceous, (glandular-)puberulous; dioecious. Leaves simple; petiole $3-8 \mathrm{~cm}$ long; blade membranous, greenish brown on drying, broadly ovate, $10-20$ by $9-18 \mathrm{~cm}$, base deeply cordate, apex acute-acuminate, margin entire, marginal teeth minute; nerves 5(-7)-palmate, puberulous-pilose; glands absent. Male inflorescences lax, 10-20 cm long, densely glandular-puberulous; bracts linear, c. $1 \mathrm{~mm}$ long. Female inflorescences paniculate or raceme-like, 5-10 cm long. Male flowers 1 (or 2) per bract in slender terminal racemes; pedicel 3-4 mm long, glabrous above the \pm median articulation; bud subglobose; perianth bowl-shaped, c. $3 \mathrm{~mm}$ wide, receptacle minute, shallow, c. $1 \mathrm{~mm}$ wide; sepals ovate-triangular, c. $1.5 \mathrm{~mm}$ long, (sparsely) hairy; petals broadly ovate-elliptic, c. $2 \mathrm{~mm}$ long, apex broadly rounded, hardly mucronate, glabrous, midvein towards base conspicuously crested adaxially. Filaments free, outcurved, c. $1 \mathrm{~mm}$ long; anthers c. $0.5 \mathrm{~mm}$ long, the theca attached to a saucer-shaped pad, with a faint brown point adaxially. Female flowers not known. Fruits 2-8 per infructescence. Capsule $5-5.5$ by $1.5(-2) \mathrm{cm}$, densely roughly pubescent, base short-acute to rounded, slightly narrowed towards apex; fruiting pedicel 


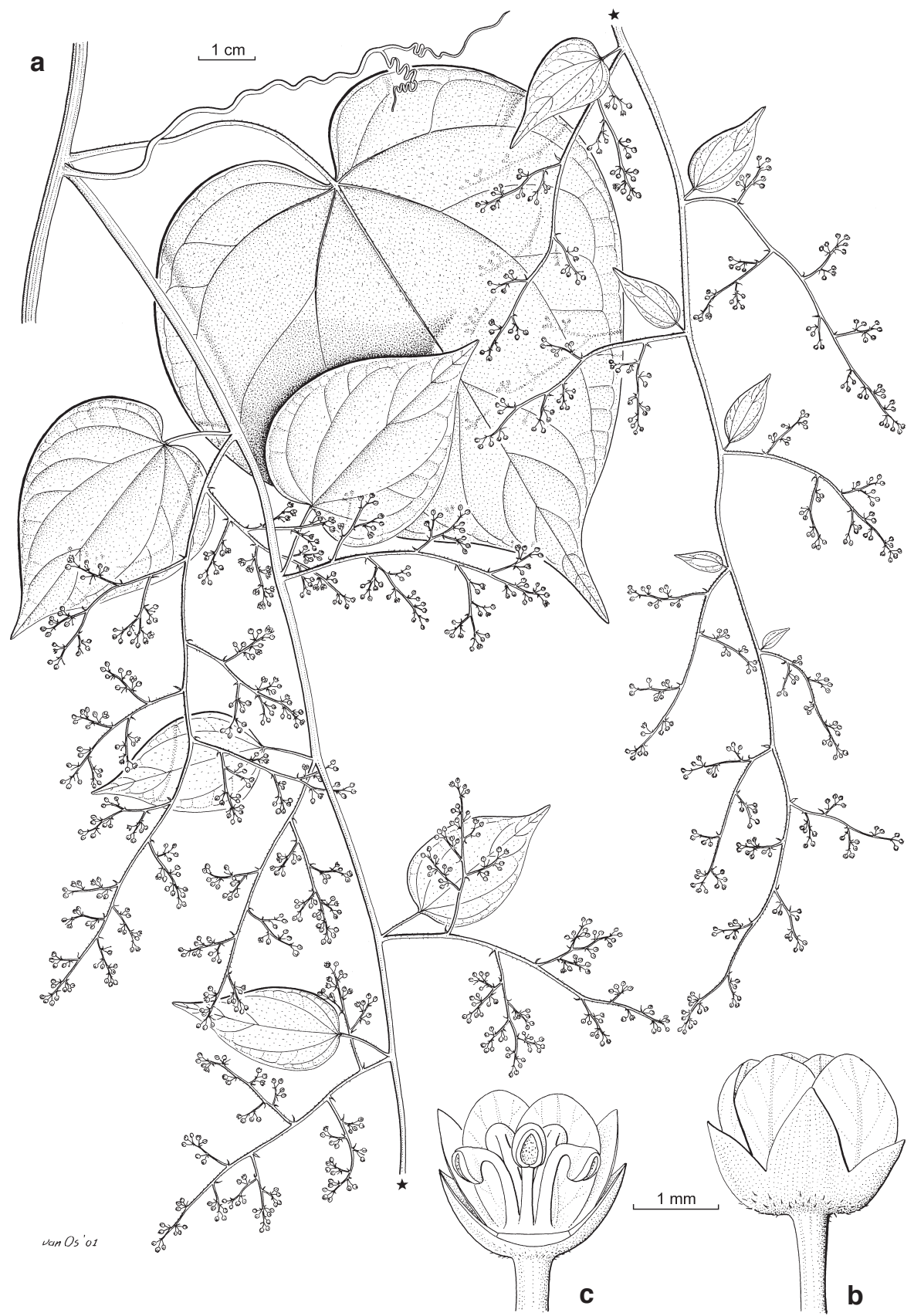

Fig. 4. Neoalsomitra simplex (Craib) Hutch. a. Habit of male inflorescence; b. male flower; c. male flower opened, showing free stamens (all: Maxwell 95-845). 


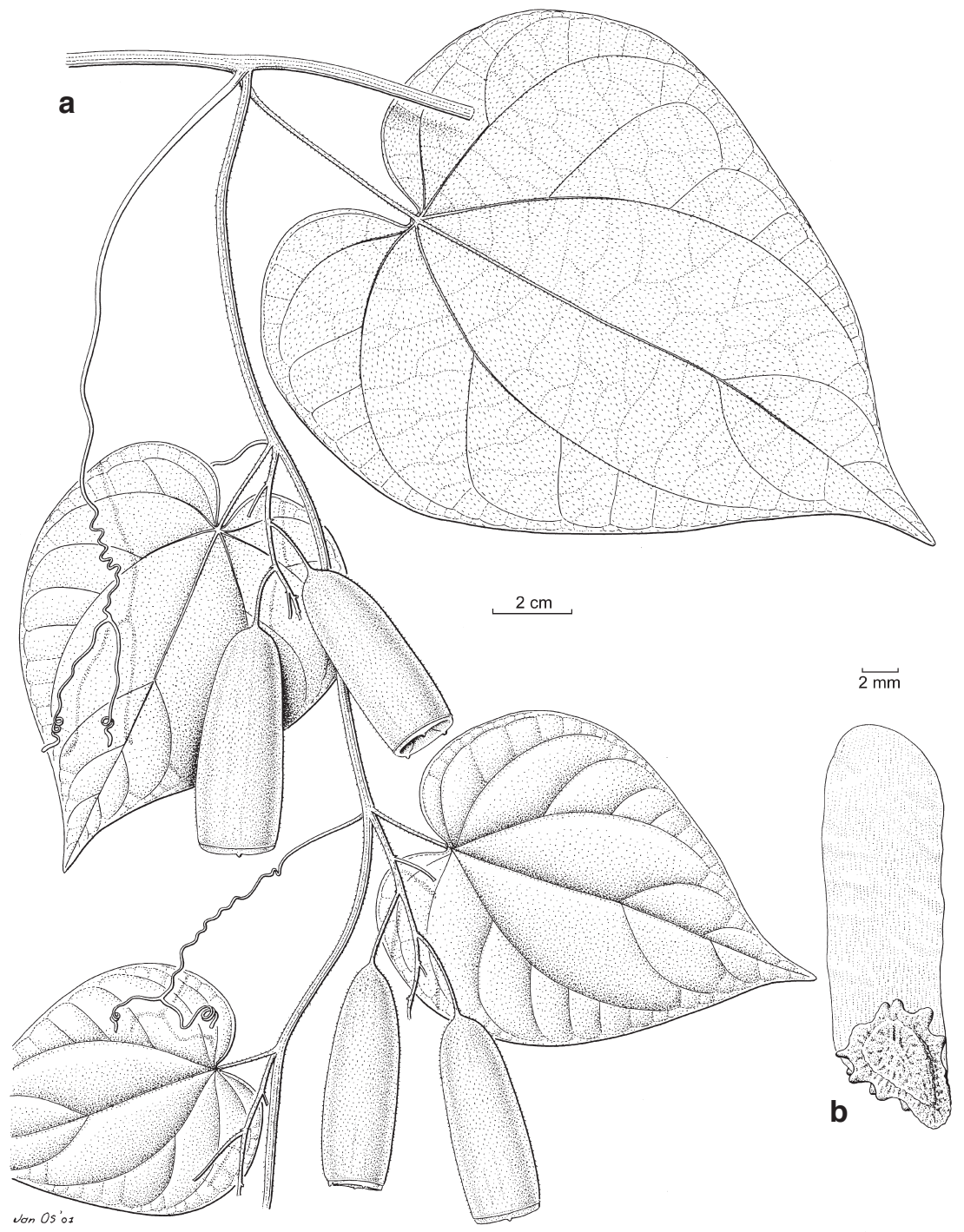

Fig. 5. - Neoalsomitra simplex (Craib) Hutch. a. Habit of fruiting branch; b. seed (all: Maxwell 89-80).

15-20 mm long, glandular pubescent. Seeds 15-20, light brown, obovate, $9-10$ by 6-7 mm, margin with 5-8 obtuse irregular teeth, faces warty-tuberculate, wing c. 18 by $6-7 \mathrm{~mm}$.

Distribution - Endemic to Thailand: Northern: Chiang Mai (Doi Chiang Dao); Peninsular: Pattani.

Habitat \& Ecology - Climbing on trees by stream in evergreen forest, and in open and disturbed evergreen thicket bordering agricultural fields; altitude 200-600 m. Male flowering: October; fruiting: January. 


\section{ACKNOWLEDGEMENTS}

We thank the directors and curators of the herbaria at BK, BKF, BM, BO, BR, BRI, CANB, K, L, MO, P and SING for making their collections available.

The hospitality received in Thailand at Bangkok Herbarium and Bangkok Forest Herbarium with opportunities for field study, greatly facilitated the understanding of the present genus. J.F. Veldkamp provided the Latin diagnosis of the new species; J.H. van Os prepared the fine drawings. J.F. Maxwell (Chiang Mai) is acknowledged for collecting rich specimens of various rare species in Thailand.

\section{REFERENCES}

Chakravarty, H.L. 1959. Monograph on Indian Cucurbitaceae. Rec. Bot. Surv. India 17: 1-234.

Chen, S.K. 1986. Neoalsomitra. In: A.M. Lu \& S.K. Chen (eds.), Fl. Reip. Pop. Sin. 73, 1: 99-102. Science Press, Beijing.

Chen, S.K. 1995. Neoalsomitra. In: C.Y. Wu, C. Chen \& S.K. Chen (eds.), Flora Yunnanica 6: 278-280. Science Press, Beijing.

Clarke, C.B. 1879. Cucurbitaceae. In: J.D. Hooker, Fl. Brit. India 2: 604-635. Reeve \& Co., London.

Cogniaux, C.A. 1881. Cucurbitaceae. In: A. \& C. de Candolle, Monogr. Phan. Prodr. 3: 325-951. Masson, Paris.

Cogniaux, C.A. 1887. Descriptions de quelques Cucurbitacées nouvelles. Bull. Acad. Roy. Sci. Belgique, Cl. Sci., sér. 3, tome 14: 346-364.

Cogniaux, C.A. 1916. Cucurbitaceae-Fevilleae et Melothrieae. In: A. Engler, Pflanzenreich 66, IV.275.1: 1-277. Engelmann, Leipzig.

Craib, W.G. 1913. Contributions to the flora of Siam. Additamenta 3. Kew Bull.: 65-72.

Craib, W.G. 1930. Contributions to the flora of Siam. Additamentum 29. Kew Bull.: 405-427.

Craib, W.G. 1931. Cucurbitaceae. Fl. Siam. En. 1: 750-770. Siam Society, Bangkok.

De Voogd, C.N.A. 1936. Naar de slijkvulkanen van Poelau Semaoe. De Tropische Natuur, jubileum uitgave: $68-72$.

Decaisne, J. 1834. Description d'un herbier de l'île de Timor. Nouv. Ann. Mus. Hist. Nat. Paris 3, 3: $333-501$.

Gagnepain, F. 1918. Cucurbitacées nouvelles de l'Herbier du Muséum. Bull. Mus. Hist. Paris 24: 371-380.

Gagnepain, F. 1921. Cucurbitacées. Fl. Gén. Indo-Chine 2: 1069-1095. Masson \& Cie., Paris.

Harms, H. 1925. Die Cucurbitaceen Papuasiens. Bot. Jahrb. Syst. 60: 150-161. Max Weg, Leipzig.

Hayata, B. 1911. Materials for a flora of Formosa. J. Coll. Sci. Imp. Univ. Tokyo 30: 1-471.

Hô, P.H. 1991. Cucurbitaceae. An illustrated flora of Vietnam 1, 2: 711-728, f. 1974-2020. Mekong printing, Santa Ana.

Hooker, J.D. 1867. Cucurbitaceae. In: G. Bentham \& J.D. Hooker, Gen. Pl. 1: 816-841. Reeve \& Co., London.

Hutchinson, J. 1942. Macrozanonia Cogn. and Alsomitra Roem. Ann. Bot. N-S, 6: 95-102.

Jacobs, M. 1954. Notes on some Malesian Cucurbitaceae. Blumea 7: 617-622.

Jacobsen, H. 1970. Das Sukkulenten Lexikon: 267, t. 112.1. Gustav Fischer Verlag, Jena.

Jeffrey, C. 1980. The Cucurbitaceae of Eastern Asia: 1-60. Roy. Bot. Gard., Kew (manuscript).

Keraudren-Aymonin, M. 1975. Cucurbitacées. In: A. Aubréville \& J.-F. Leroy (eds.), Flore du Cambodge, du Laos et du Viêt-nam 15: 1-114. Mus. Nat. d'Hist. Nat., Paris.

Merrill, E.D. 1908. New or notew orthy Philippine plants, VI. Philipp. J. Sci., Bot. 3: 219-267.

Merrill, E.D. 1918. New or noteworthy Philippine plants, XIII. Philipp. J. Sci., Bot. 13: 1-66.

Merrill, E.D. \& L.M. Perry. 1949. Plantae Papuanae Archboldianae, XVIII. J. Arnold Arbor. 30: 39-63.

Miquel, F.A.W. 1856. Cucurbitaceae. Fl. Ind. Bat. 1, 1: 652-683. Van der Post, Amsterdam.

Mueller, F.J.H. 1866. Fragmenta phytographiae Australiae 5. J. Ferres, Melbourne. 
Mueller, F.J.H. 1868. Fragmenta phytographiae Australiae 6. J. Ferres, Melbourne.

Mueller, F.J.H. 1870. Fragmenta phytographiae Australiae 7. J. Ferres, Melbourne.

Mueller, F.J.H. 1874. Fragmenta phytographiae Australiae 8. J. Ferres, Melbourne.

Mueller, F.J.H. 1882. Systematic census of Australian plants. M'Carron, Bird \& Co., Melbourne.

Newton, L.E. \& G.N. Njoroge. 2002. In: U. Eggli (ed.), Illustrated handbook of succulent plants: Dicotyledons: 90 . Berlin, Heidelberg, Springer.

Peekel, P.G. 1984. Flora of the Bismarck Archipelago for naturalists: 540-551. Translated by E.E. Henty. Kristen Pres, Madang.

Prain, D. 1898. In: G. King \& D. Prain, Descriptions of some new plants from the north-eastern frontiers of India. J. Asiat. Soc. Bengal, Pt. 2, Nat. Hist. 68: 284-305.

Roemer, M.J. 1846. Peponiferarum. Syn. Monogr. 2: 1-118. Landes-Industrie-Comptoirs, Weimar.

Schumann, K.M. 1898. Die Flora von Neu-Pommern. Notizbl. Königl. Bot. Gart. Berlin 2, 13: $155-156$.

Spanoghe, J.B. 1841. Prodromus Florae Timorensis. Linnaea 15: 161-208.

Telford, I.R. 1982. Cucurbitaceae. Fl. Austr. 8: 158-198, 205.

Van Steenis, C.G.G.J. 1955. Miscellaneous botanical notes VII. 56. A new Neoalsomitra from South Malaysia (Cuc.). Blumea 8: 171-174.

Van Steenis, C.G.G.J. 1956 ('1955'). Podagric plants in Malaysia. Webbia 11: 189-195.

Van Steenis-Kruseman, M.J. 1950. Flora Malesiana I, 1. Noordhoff-Kolff N.V., Djakarta.

Van Woerden, C. 1940. Succulenten in Nederlandsch Oost-Indië. De Tropische Natuur 29, 1 : $1-15$.

Wallich, N. 1831a. A numerical list of dried specimens of plants in the East India Company's museum. Mimeograph, East India House, London.

Wallich, N. 1831b. Plantae asiaticae rariores 2. Treuttel \& Würtz, London.

Walpers, W.G. 1843. Repertorium botanices systematicae 2. Hofmeister, Leipzig.

\section{IDENTIFICATION LIST}

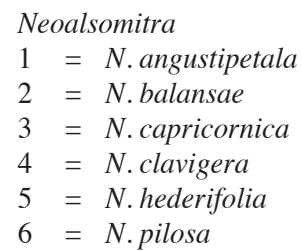

$$
\begin{aligned}
& 7=N . \text { plena } \\
& 8=N . \text { sarcophylla } \\
& 9 \mathrm{a}=\text { N. schefferiana } \text { subsp. schefferiana } \\
& 9 \mathrm{~b}=\text { N. schefferiana } \text { subsp. podagrica } \\
& 10=N . \text { schultzei } \\
& 11=N . \text { simplex }
\end{aligned}
$$

Alston 17128: 8 - Anonymous in herb. d'Alleizette: 4; 521, in herb. Decaisne (barcode P218602): 5; (barcode P218603): 5; (barcode P218601): 5; cultivated bot. garden Bogor XII-B-153 \& XII-B153a: 8; cultivated bot. garden Bogor XVIII-A-45,30 Apr.1955: 9b; cultivated bot. garden Bogor XVIII-A-45a, 30 Apr. 1955: 9b; cultivated bot. garden Bogor XVIII-A-45a, probably 17 Mar. 1955: 9b; cultivated bot. garden Bogor XVIII-A-45, 17 Mar. 1955: 9b; cultivated bot. garden Bogor XVIII-A-45, 19 Mar. 1960: 9b; HLB 901287475: 4; HLB 901289102: 4 - Avé 4835: 9a.

Backer 26948: 5 - Baenitz 2049: 8 - Balansa 4022: 2; 4024: 4 - Beccari (Key Is.): 4 - Bicknell 1631: 4 - Bon 3247: 2; 6141: 8 - Brass 3606: 4; 8116: 4; 8149: 10; 29237: 4 - BS (Fénix) 30068: 4; (Ramos \& Edaño) 40519: 4 - BSIP (Mauriasi et al.) 15669: 4.

Carr 12477: 6; 14537: 4; 15873: 6; 16295: 4; - S.Q. Chen 11306: 4 - Chuang 3172: 4 - Clarke 27042: 4 - Collins 2007: 8 - Cuming 517: 4; 767: 4.

De Voogd Nov. 1938: 9b; 2323: 5 - De Wilde \& Duyfjes 21761: 4; 21799: 4; 21846: 9a; 21856: 8; 21899: 9a; 22148: 1; 22169: 1; 22175: 4; 22181: 8; 22268: 1 - De Wit HLB 95060245, cultivated bot. garden Leiden, 07 Feb. 1950: 9b - Dietrich 1463: 3 - Djoemadi 14, cultivated bot. garden Bogor XVIII-A-44, 19 Mar. 1960: 9b - Durand 2689: 8.

Elmer 17035: 4; $17353: 4$.

FB (Ahern's collector) 3409: 4 - Forrest 13681: 4. 
Gamble Sept. 1873: 4; 3939A: 4; 3939B: 4 - Geesink \& Hiepko 7893: 8.

Hanif \& Nur 7561: 4 - Hartley TGH 10083: 4 - Helfer 2520:4 - Hoogland 4575: 4 - Hooker Mar. 1850: 4; HLB 9012877 (also at K): 4 - Hooker \& Thompson 2160: 4 - Huk Dec. 1890: 8.

Jaag 888: 9b; 819: 9b - Jaheri 250: 4.

Kaudern 451: 4 - Kerr 4 Jan. 1923: 8; 4 July 1927: 8; 1332: 1; 1946: 1; 6463: 4; 7524: 11; 9869: 4; 16191: 7; 16191A: 7; 17661: 8; 19985: 1 - Kjellberg 1673: 8 - Kornassi 1433: 9a - Kostermans 1553: 4.

LAE (Kerenga) 73815: 4 — Lakshnakara 1408: 8; 1510: 8; 1540: 8 - Larsen et al. 31701: 1 - Liu Xinqi 28106: 4 - Loher 6082: 4.

Marcan 1889: 4 - Maxwell 71-316: 8; 73-604: 8; 74-760: 1; 74-1006: 8; 75-687; 76-2: 8; 76-17: 8; 76-366: 1; 76-367: 1; 88-1320: 4; 88-1378: 8; 89-80 (fr.): 11; 89-984: 1; 89-1558: 4; 93-1047: 1; 94-1196: 4; 96-1446: 4; 95-845 (male): 11; 00-163: 8 - McDonald \& Ismail 4046: 8 - Meijer 10769: 9a - Mokim Jan. 1898, fruit: 4; Nov. 1897, male: 4 - Mueller barcode L1623: 4.

Naino 106: 7 - NGF (Millar) 9934: 4; (White) 11152: 4; (Millar) 12261: 4; (Van Royen) 16264: 4; (Van Royen) 16316: 4; (Henty \& Coode) 29207: 4; (Kairo \& Emos) 30980: 4; (Coode \& Dockrill) 32650: 4; (Streimann \& Kairo) 35813: 4; (Kairo) 44571: 4; (Streimann) 47807: 4.

Parker 2450: 4 - Parry 1009: 4 - Pleyte cultivated bot. garden Bogor II-0-X-6: 9b; cultivated bot. garden Bogor XVIII-A-44, 06 May 1954: 9b; cultivated bot. garden Bogor XVIII-A-45a (a deleted), 06 May 1954: 9b; cultivated bot. garden Bogor XVIII-A-45a, 16 Oct. 1954: 9b - PNH (Sulit) 16991: 4 - Poilane 03 Feb. 1932: 8; 11767: 8 - Pooma 1273: 1 - Pooma et al. 2102: 7; 3023: 7; 3037: 1 - Prayad 637: 4 - Pullen 6847: 10 - Put 1384: 8; 2650: 1; 3071: 1; 3087: 1; 4109: 1.

Sakol 531: 8 - Schmutz 2361: 8 - SF (Henderson) 29154: 4 - Shimizu et al. T11496: 4; T23648: 8 - SMHI (Ridsdale) 200: 8 - Smitinand 4864: 8; 4865: 8 - Smitinand et al. 1351: 7 - Sutheesom 3172: 1 .

Takeuchi 6674: 4 - Teijsmann 11854: 9a; 19765: 8 - Treutler 710: 4.

Van Beusekom et al. 3409: 7 - Van Steenis 18015: 8; 18016: 8 - Van Steenis ex De Voogd, cultivated in garden of Van Steenis, probable date 1939: 9b; ex De Voogd, cultivated in garden of Van Steenis, Nov. 1940: 9b; HLB 935018321, cultivated bot. garden Leiden, Aug. 1954: 9b - Van Vuuren 277: 4.

Wallich 3724A: 8; 3724B: 8; 3725A: 4; 3725B: 4 - Winit 1422: 1; 1734: 1- Wongprasert 25 Oct. 1998: 1.

\section{INDEX}

Accepted taxa are in roman type, new taxa in bold and synonyms in italics. Numbers refer to the species number as used in this revision.

Alsomitra M. Roem. [p. 100]
angustipetala (Craib) Craib 1
balansae Gagnep. 2
beccariana Cogn. 4
capricornica F. Muell. 3
clavigera (Wall.) M. Roem. 4
var. hookeri C. B. Clarke 4
hookeri F. Muell. 4
integrifoliola (Cogn.) Hayata 4
muelleri Cogn. 4
philippinensis Cogn. 8
plena Craib 7
pubescens Merr. 4
pubigera Prain 4
var. glauca Craib 4
rotundifolia Cogn. 4
sarcophylla M. Roem. 8

\author{
(Alsomitra) \\ schefferiana Cogn. 9 \\ var. minor Cogn. 9 \\ schefferiana auct. 4 \\ schultzei Cogn. 10 \\ simplex Craib 11 \\ spec. Woerden $9 \mathrm{~b}$ \\ stephensiana (F. Muell.) Cogn. 4 \\ timorana (Span.) M. Roem. 5 \\ tonkinensis Gagnep. 4 \\ trifoliolata (F. Muell.) K. Schum. 4 \\ Gynostemma angustipetala Craib 1 \\ elongatum Merr. 4 \\ ?hederifolia (Decne.) Cogn. 5 \\ integrifoliola Cogn. 4 \\ spec. C. de Voogd 5
}




\author{
Hemsleya elongatum (Merr.) Cogn. 4 \\ henryi Cogn. 4 \\ Melothria trifoliolata F. Muell. 4 \\ Neoalsomitra Hutch. [p. 100] \\ angustipetala (Craib) Hutch. 1 \\ balansae (Gagnep.) Hutch. 2 \\ beccariana (Cogn.) Hutch. 4 \\ capricornica (F. Muell.) Hutch. 3 \\ clavigera (Wall.) Hutch. 4 \\ hederifolia (Decne.) W.J. de Wilde \\ \& Duyfjes 5 \\ integrifoliola (Cogn.) Hutch. 4 \\ muelleri (Cogn.) Hutch. 4 \\ philippinensis (Cogn.) Hutch. 8 \\ pilosa W.J. de Wilde \& Duyfjes 6 \\ plena (Craib) Hutch. 7 \\ podagrica Steenis $9 \mathrm{~b}$ \\ pubescens (Merr.) Hutch. 4 \\ pubigera (Prain) Hutch. 4 \\ rotundifolia (Cogn.) Hutch. 4
}

(Neoalsomitra)

sarcophylla (Wall.) Hutch. 8

schefferiana (Cogn.) Hutch. 9

subsp. podagrica (Steenis) W.J. de Wilde

\& Duyfjes 9b

subsp. schefferiana 9a

schultzei (Cogn.) Hutch. 10

simplex (Craib) Hutch. 11

stephensiana (F. Muell.) Hutch. 4

timorana (Span.) Hutch. 5

tonkinensis (Gagnep.) Hutch. 4

trifoliolata (F. Muell.) Hutch. 4

Sicyos hederifolius Decne. 5

Zanonia clavigera Wall. 4

hookeri F. Muell. 4

integerrima Wall. 4

sarcophylla Wall. 8

stephensiana F. Muell. 4

timorana Span. 5 